\title{
Epidermal hydration seems to influence the tension directionality in the forearm
}

\section{A hidratação epidérmica parece influenciar a direccionalidade da tensão no antebraço}

\author{
Luis Monteiro Rodrigues ${ }^{1,2}$, Claudia Conduto ${ }^{2}$, Pedro Contreiras Pinto ${ }^{1}$ \\ 'CBIOS - Experimental Dermatology Unit, Fac. Ciências e Tecnologias da Saúde, \\ Universidade Lusófona, Lisboa, Portugal \\ ${ }^{2}$ Lab,of Experimental Physiology, Universidade de Lisboa-Fac. Farmácia, Lisboa, Portugal \\ E-mail: monteirorodrigues.dcs@ulusofona.pt
}

\begin{abstract}
Abstrac
Langer lines shows the tensional direction of the skin, e.g., its anisotropy but, a clear relationship between dermal changes and epidermal directionality, as it happens in skin ageing, is not known. Since the quantification of the in vivo anisotropy is already possible, we've tried to study the impact of epidermal hydration on the mechanical direction of humanskin.

The study involved twelve healthy women, grouped by their age. The viscoelastic racio(Uv/Ue) obtained by the do Cutometer@ SEM575 system, and the RRT (ressonance running time) obtained with the Reviscometer@ RVM600 device were measured in the ventral forearm.

Measurements took place at time zero and after a $24 \mathrm{~h}$ occlusive patch. Both groups behaved similarly before and after occlusion regarding both viscoelastic racio and RRT, although variables were always higher in the older group. Nevertheless, occlusion increased RRT and decreased anisotropy. And these changes were again more pronounced in the older individuals group.

No matter the obviously insufficient number of volunteers, results suggest the interest in knowing further how epidermis influences the biomechanical behavior of the human skin.
\end{abstract}

Keywords: Langer lines; anisotropy; directionality; biomechanics; epidermis

\begin{abstract}
Resumo
As linhas de Langer são indicador da direç̧ãotensional da pele e, portanto, da sua anisotropia mas não se conhece a relação entre a alteração da derme e a direccionalidade da epiderme como acontece no envelhecimento cutâneo. Sendo possivel quantificar a anisotropia in vivo, procurámos estudar o impacto da hidratação da epiderme na direcção mecânica da pele humana.

O estudo envolveu doze mulheres, saudáveis, agrupadas por idades. $\mathrm{Na}$ face ventral do antebraço foram medidos o rácio viscoelástíco (Uv/Ue) obtido através do Cutometerß SEM575 e o RRT (ressonance running time), obtido através do Reviscometerß RVM600. As medições foram efectuadas no tempo zero e após aplicação de um penso oclusivo por $24 \mathrm{~h}$. Ambos os grupos mostraram comportamento semelhantes antes e após oclusẫo para $o$ indice viscoelástico eparao RRT, embora se observasse um aumento do valor das variáveis no grupo dos voluntários mais velhos. Contudo a oclusão aumentou o RRT e diminuiu a anisotropia, E estas variações foram sempre mais marcadas no grupo de individuos mais velhos.

Apesar do evidente número reduzido de voluntários, os resultados sugerem o interesse em melhor conhecer a influência da epiderme sobre o comportamento biomecânico da pele in vivo.
\end{abstract}

Palavras - chave: Linhasde Langer; anisotropia; direccionalidade; biomecânica; epiderme 


\section{Introduction}

From the biomechanic's perspective, the human skin is particularly complex since it's not a truly plastic or an elastic material, with a non linear anisotropic behavior ${ }^{(11,2,7)}$, permanently submitted to a pretension, as visually shown by the Langer's lines ${ }^{0-1}$. These Langer lines, distributed all over the body, represents skin's maximal tension directions, and this is particularly important in surgery since any incision should follow this orientation. Lower tension facilitates healing and improves aesthetical appearance, ${ }^{(4-6)}$.

No matter the multiple difficulties involved, in vivo skin biomechanical characterization may be achieved by several descriptors, mostly obtained by specifically designed non invasive technologies, allowing to explore many complex pathophysiological processes such as ageing ${ }^{(2)}$. However this information is always hard to understand since this behavior depends from a structural organization that is still insufficiently known, although recognizing that the collagen and elastin network, the surrounding glucosaminoglicane matrix, and epidermis are major actors ${ }^{17.9}$. A special remark is due to the dermal collagen "arquitecture" to which the most important biomechanical support of the skin is attributed (10,11). Actually its typical apparently random distribution seems to change in some pathologies, showing a more regular collagen alignment with epidermis ${ }^{1,10,35}$. We actually know that these help to explain macro and micro-depressionary changes at skin's surface. But to explain with adequate detail, which mechanisms (biophysical and patophysiological) determine skin ageing and wrinkling, specially regarding changes in dermal arquitecture orientation and its relation with related epidermal modification, is far from being possible ${ }^{[3, \rho]}$. Several studies were developed to relate human skin's biomechanics and histology but, in practical terms, it only confirmed skin's anisotropy with no mention to fiber's directionality ${ }^{(11)}$. Nevertheless, some recent studies, with image analysis, seems to be able to go further ${ }^{[4,12\}}$. There are no methods to non-invasively assess Langer lines but, recently, a new system - the Reviscometer RVM600 is referred to measure elastic fibers orienation, from the epidermal surface, by electroacustic waves ${ }^{(13-5)}$. Results suggested a good correlation between anisotropy and Langer lines changes with ageing, in the in vivo human forearm ${ }^{106)}$. And the application to other anatomical áreas ${ }^{(5)}$, studying mechanical changes with ageing, seems to reinforce the interest in the system. So, under these views, the present study intends to approach the impact of epidermal's hydration in the mechanical direction of human skin.

\section{Introdução}

Do ponto de vista biomecânico, a pele humana é especialmente complexa, na medida em que não sendo um material verdadeiramente elástico ou plástico, comporta-se de forma anisotrópica e não linear ${ }^{0.27}$, sempre sujeita a uma pré-tensão permanente, como se revela a olho nú pelas linhas de Langer ${ }^{(1-4)}$. Estas linhas de Langer, distribuidas por toda a superficie corporal, representam as direcçôes máximas de tensão da pele o que é especialmente importante do ponto de vista cirúrgico já que a incisão deve seguir estas linhas de orientação, ou seja, procurar as direç̧ões de menor tensão, de forma a facilitar o processo de cicatrização e melhorar a aparência estética, ${ }^{1466}$.

Apesar das dificuldades que o tema envolve, a caracterização biomecânica da pele in vivo pode ser conseguida através de vários "descriptores", obtidos sobretudo por tecnologias não-invasivas desenvolvidas com este propósito, e através das quais processos patofisiológicos complexos, como o envelhecimento, entre outros, têm podido ser explorados ${ }^{(2)}$. Contudo, a informação recolhida é sempre de difícil interpretação já que este comportamento é determinado por uma organização estrutural ainda mal compreendida, onde a rede de colagéneo e elastina, a matriz de glucosaminoglicanos envolvente e, a epiderme, desempenham os papéis principais (5-5). E aqui referimos, em especial, a "arquitectura" do colagénio dérmico, ao qual se atribui a maior responsabilidade do suporte biomecânico da pele ${ }^{00,11}$. De facto, a sua aparente distríbuição aleatória na derme, parece alterarse em algumas situações patológicas, revelando-se por um alinhamento mais ordenado do colagénio com a epiderme ${ }^{(4,1,0,1)}$. Por outro lado, apesar de sabermos que é destas alterações que surgem as modificações macro e micro-depressionárias da superficie cutânea, não é ainda possivel descrever com o adequado detalhe, os mecanismos (biofisicos e fisiopatológicos) subjacentes ao envelhecimento cutâneo e à formação das rugas, designadamente no que respeita à identificação das alterações de orientação da arquitectura dérmica e sua relação com as modificações epidérmicas que dai resultam $(5,6)$. Vários estudos têm sido desenvolvidos para relacionar o comportamento mecânico da pele humana com a sua histologia mas, na prática, apenas têm conseguido demonstrar a extensão da anisotropia do tecido sem informar sobre a direccionalidade das fibras (in! embora estudos mais recentes pareçam conseguir ir mais longe através, sobretudo, da utilização de análise de imagem ${ }^{(4,12)}$.

Também não existem métodos para medir, de forma não invasiva, as linhas de Langer mas, recentemente, um novo sistema - o Reviscometer RVM600 propôs-se medir a direcção das fibras elásticas através da superfície epidérmica, por meio de ondas 


\section{Material and Methods}

Twelve female healthy volunteers were included in the study following informed written consent. All the procedures were according the general principles of human experiments and fulfill the ethical guidelines of the Helsinki declaration and subsequent amendments ${ }^{(17,18)}$. The volunteers were divided into Group 1 , with younger individuals $(\mathrm{n}=6$, mean age $22.5 \pm 0.55$ years old), and Group II, with older individuals ( $\mathrm{n}=6$, mean age $48.3 \pm 10,6$ years old). The selection criteria also included phototype lower than V, absence of history of cutaneous or other diseases, absence of application of topical products in the ventral area of the forearm (measurement site) in the previous $24 \mathrm{H}$ of the measurements. The forearm was randomly selected, and the evaluation sites were defined in the ventral area. The experimental procedure was performed under controlled temperature and relative humidity $\left(20^{\circ} \mathrm{C}-22^{\circ} \mathrm{C} ; 50\right.$ $60 \%$ ), ensuring that all the volunteers experienced an adaptation period to the room conditions of at least 15 minutes, as described in the literature ${ }^{01,14,19}$.

The variables considered relevant for the main purposes of the study were the viscoelastic ratio (Uv/Ue) obtained through the Cutometer' SEM575 (Courage and Khazaka, Koln, Germany) equipped with a $8 \mathrm{~mm}$ diameter probe, and the RRT (Resonance Running Time) calculated in seconds, obtained through the Reviscometer ${ }^{2}$ RVM600 (Courage and Khazaka, Koln, Germany). The RRT was measured at several angles $\left(0^{\circ}, 45^{\circ}, 90^{\circ}\right.$ and $\left.135^{\circ}\right)$ with a minimum of 4 measurements in each site and in each angle 10 (Figure 1) (RRT mean). The maximum (RRTmax) and minimum (RRTmin) values were also measured in each individual. The variables were measured in two sites, one served as control while in the other there was an application of an occlusive system during $24 \mathrm{H}$. The occlusive system has an area of $4 \mathrm{~cm} 2$ with several layers of plastic film, Parafilm ${ }^{\circ}$ (Pechiney Plastic Packaging, Chicago, IL, E.U.A.) and gauze, adherent to the skin with surgical adhesive (Leukoplast, Beiersdorf SA, Hamburg, Germany) ${ }^{(0)}$. The measurements were repeated after the occlusion removal, and elimination of the water excess present in the skin surface, with absorbent paper.

The statistical analysis was performed with SPSS (version 13.0 for Windows) and Microsoft Excel * 2003 , involving the Wilcoxon and Mann-Whitney non parametric tests and the Spearman correlation for paired data. A significance level of $95 \%$ was adopted. electroacústicas (13-16). Alguns resultados parecem sugerir uma boa correlação entre a anisotropia assim medida no antebraço humano, in vivo, e as alteraçōes das linhas de Langer dependentes da idade (16). E a sua aplicação a outras regiōes anatómicas na caracterização mecânica do envelhecimento (5) parece reforçar o potencial interesse deste sistema. Neste enquadramento, o presente estudo, pretende estudar o impacto da hidratação da epiderme na direç̧ão mecânica da pele humana.

\section{Material e Métodos}

Participaram no estudo doze voluntários do sexo feminino, saudáveis, devidamente informados após consentimento informado escrito. Todos os procedimentos seguiram os principios gerais relativos à experimentação humana, respeitando todas as normas éticas previstas pela Declaração de Helsínquia e respectivas emendas ${ }^{(12,3)}$. As voluntárias foram separadas por idades em Grupo I, constituido por individuos mais jovens $(n=6)$ com idade média $22.5 \pm 0.55$ anos, e Grupo II, constituido por individuos mais velhos $(\mathrm{n}=6)$ com idade média $48.3 \pm 10,6$ anos. A selecção dos voluntários incluiu ainda, fototipo inferior a V, ausência de historial de doenças cutåneas ou outras, e abstenção de aplicação de produtos tópicos no antebraço ventral (local de medição) nas $24 \mathrm{~h}$ que antecederam as mediçǒes. $O$ antebraço de medição foi escolhido aleatoriamente, marcando-se na sua face ventral, os sitios de avaliação.

$O$ procedimento experimental decorreu em condições de temperatura e humidade controladas $\left(20^{\circ} \mathrm{C}-22^{\circ} \mathrm{C} ; 50\right.$ $60 \%$ ), assegurando a adaptação prévia dos voluntários durante pelo menos, 15 minutos, como se encontra descrito na literatura ${ }^{(1,14,13 \%}$.

As variáveis consideradas como relevantes para os objectivos do estudo foram o rácio viscoelástico (Uv/Ue) obtido através do Cutometer ${ }^{*}$ SEM575 (Courage and Khazaka, Colónia, Alemanha) equipado com uma sonda de $8 \mathrm{~mm}$ de diâmetro, e o RRT (ressonance running time) expresso em segundos, obtido através do Reviscometer RVM600 (Courage and Khazaka, Colónia, Alemanha). 0 RRT é medido $\mathrm{cm}$ vários ângulos $\left(0^{\circ}, 45^{\circ}, 90^{\circ}\right.$ e $\left.135^{\circ}\right)$ com um mínimo de 4 medições em cada sitio e em cada ângulo 10 (Figura 1) (RRT médio) , registando-se também os valores máximo (RRTmax) e mínimo (RRTmin) para cada individuo. As variáveis foram medidas em 2 sítios, servindo um de controle enquanto ao outro foi aplicado um penso oclusivo durante 24horas. $\mathrm{O}$ sistema oclusivo ocupa cerca de $4 \mathrm{~cm} 2$ de área, e consiste em camadas sobrepostas de pelicula aderente, Parafilm ${ }^{\circ}$ (Pechiney Plastic Packaging, Chicago, IL, E.U.A.) e gaze, fixadas à pele com adesivo cirúrgico (Leukoplast, Beiersdorf SA, Hamburgo, Alemanha) ${ }^{[2]}$. As mediçỏes foram repetidas após remoção do penso oclusivo e eliminaçăo, com papel adsorvente, do excesso de água presente à superfície da pele.

A análise estatistica foi realizada com o programa SPSS 
(versão 13.0 para Windows) e Microsoft Excel $\otimes 2003$, e envolveu os testes não paramétricos Wilcoxon e MannWhitney e teste Spearman para dados emparelhados, adoptando-se um nivel de confiança de $95 \%$.

a)

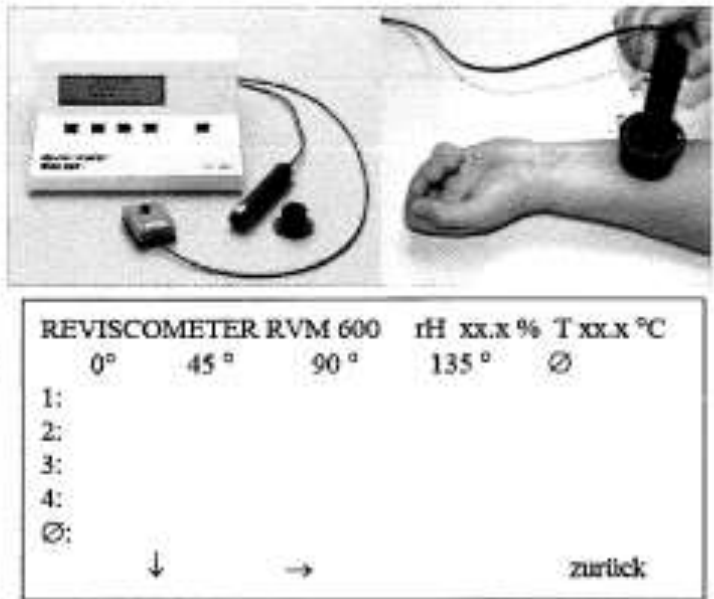

b)

Figure 1 - a) Reviscometer(5) RVM 600; b) probe position during RRT measurement; c) RRT registration panel in diferent angles (adapted from 13).

Figura 1 - a) Reviscometer RVM 600; b) Posição da sonda durante a medição de RRT; c) quadro de registo de RRT segundo os diferentes ângulos (adaptado de 13).

\section{Results and Discussion}

One of the greatest difficulties associated to in vivo studies is the high inter-individual variability. In order to by-pass this difficulty, data was analysed as a ratio of the results obtained in relation to the basal values. Thus, results that are close to one indicate a low impact, whereas higher or lower values are suggestive of the opposite. Such results can be found on table 1 .

\section{Resultados e Discussão}

Para reduzir a influência da variabilidade inter-individual dos voluntários e, tendo em consideração que os valores das mediçōes efectuadas em cada dia são influenciados por diversos factores, o valor obtido na medição da zona de aplicação foi dividido pelo respectivo valor basal. Deste modo, considera-se a unidade "1" como o valor base, pelo que acima deste valor teremos um aumento da variável e abaixo deste valor uma diminuição da mesma. Os resultados encontram-se resumidos na tabela 1.

Table 1 - Mean results for variables Uv/Ue, RRT (normalized) and Anisotropy obtaine at control and occlusion sites

Tabela 1 - Resultados médios das variáveis Uv/Ue, RRT (normalizado) e Anisotropia, obtidas nas zonas de medição controlo e de oclusão

\begin{tabular}{|c|c|c|c|c|c|c|}
\hline & \multicolumn{2}{|c|}{ Uv/Ue (mm) } & \multicolumn{2}{c|}{$\begin{array}{c}\text { RRTmean (normalised) } \\
\text { RRTmédio (normalizado) }\end{array}$} & \multicolumn{2}{c|}{$\begin{array}{c}\text { Anisotropy } \\
\text { Anisotropia }\end{array}$} \\
\hline & $\begin{array}{c}\text { Group I } \\
\text { Grupo I }\end{array}$ & $\begin{array}{c}\text { Group II } \\
\text { Grupo II }\end{array}$ & $\begin{array}{c}\text { Group I } \\
\text { Grupo I }\end{array}$ & $\begin{array}{c}\text { Group II } \\
\text { Grupo II }\end{array}$ & $\begin{array}{c}\text { Group I } \\
\text { Grupo I }\end{array}$ & $\begin{array}{c}\text { Group II } \\
\text { Grupo II }\end{array}$ \\
\hline $\begin{array}{c}\text { Control } \\
\text { Controlo }\end{array}$ & $0.921 \pm 0.257$ & $0.646 \pm 0.105$ & $1.040 \pm 0.131$ & $1.015 \pm 0.154$ & $2.212 \pm 0.213$ & $2.830 \pm 0.657$ \\
\hline $\begin{array}{c}\text { Occlusion } \\
\text { Oelusăo }\end{array}$ & $1.042 \pm 0.330$ & $1.931 \pm 0.670$ & $1.256 \pm 0.100$ & $1.425 \pm 0.249$ & $1.991 \pm 0.716$ & $2.254 \pm 0.923$ \\
\hline
\end{tabular}


Comparison of the viscoelastic index and RRT results obtained in time zero (basal) before the application of the occlusive patch, has not revealed significant differences between the two groups of volunteers ( $p$ > 0.699 ), even though an increase in the variables obtained in the older volunteers was observed (table 1). Occlusion is a well known provocation technique that has been employed to overhydrate the epidermis and, thus, study effects that are related ${ }^{20,23)}$.

In what concerns the viscoelastic index (Uv/Ue), it can be observed that the mean values obtained with the $8 \mathrm{~mm}$ probe after occlusion are bigger than one. The viscoelastic ratio is one of the most commonly used descriptors to characterize the biomechanics of human skin in vivo, and corresponds to the ratio between the biomechanical behavior that results from delayed stretching (Uv) and the immediate deformation that occurs after suction (Ue). Nevertheless, in the current experimental conditions, occlusion has not significantly increased the viscoelastic index $(p=0,10)$, even though, according to the literature, hydrated skin is associated to an increase in the viscoelastic reason ${ }^{(2,2,24)}$

RRT, expressed as mean value (RRTmean) of the measurements performed in any of the previously mentioned angles corresponds to the propagation time of the acoustic wave through a media, which seems to vary according to the elasticity and the skin water content ${ }^{(1 \mathrm{it}, 19}$. The RRTmax / RRTmin ratio that is calculated for each site is widely accepted as an indicator or anisotropy ${ }^{(5, i s\}}$. The hydration increase that is caused by the $24 \mathrm{H}$ occlusion seems to be responsible by the increase in RRTmean, that is, propagation becomes siower when there is an excess of water molecules. A recently published study suggests that an induced skin dehydration in the volar forearm by application of an alkaline soap decreases $\mathrm{RRT}^{(14)}$, and it can be inferred that hydration should, therefore, increase it. Results have also shown that after occlusion the acoustic wave propagates slower in group II than in group I, even though a statistical significance could not be established (figure 2).

It can be admitted that a higher RRTmean can denote less elasticity, which is compatible with the structural changes that occur in the ageing process and, specially, in the degradation of the collagen-elastin network ${ }^{(i)}$. Also related to ageing are reports of an anisotropy increase in the internal surface of the ventral arm and forearm of older individuals ${ }^{06,25}$. However, the current differences established in anisotropy did not have a statistical significance, even after occlusion (figure 3).
A comparação dos resultados obtidos no tempo zero (basal) antes da aplicação do penso oclusivo, para o indice viscoelástico e para o RRT, não revelou diferenças significativas entre os 2 grupos de voluntários ( $>>0.699$ ) apesar de se observar um aumento do valor das variáveis no grupo dos voluntários mais velhos (tabela 1).

A oclusão é uma técnica de provocação amplamente testada para sobrehidratar a epiderme e assim estudar os efeitos relacionados ${ }^{[01,223}$

No que respeita ao indice viscoelástico (Uv/Ue), os valores médios obtidos com a sonda de $8 \mathrm{~mm}$ de diâmetro após oclusão são superiores à unidade. $\mathrm{O}$ rácio viscoelástico é um dos descriptores mais frequentemente utilizados na caracterização biomecânica da pele humana in vivo correspondendo ao quociente entre o comportamento biomecânico proveniente da distensão atrasada (Uv) e a deformação imediata após sucção (Ue). Contudo, nas presentes condições experimentais, a oclusão não aumenta significativamente o índice viscoelático $(\mathrm{p}=0,10)$ embora, de acordo com anteriores trabalhos, a pele hidratada seja associada ao aumento da razäo viscoelástica ${ }^{[23,210}$

O RRT, expresso como valor médio (RRTmédio) das medições efectuadas em cada um dos ângulos indicados, corresponde ao tempo de propagação da onda acústica, através do meio, do emissor ao recetor, o qual parece variar de acordo com a elasticidade e o teor em água da pele ${ }^{(0,19)}$. A razão RRTmax / RRTmin calculada em cada sítio é aceite como indicador quantitativo da anisotropia ${ }^{(5.15)}$. A hidratação evocada pela oclusão $24 \mathrm{~h}$ parece ser a responsável pelo aumento do RRTmédio, ou seja, a condução torna-se mais lenta com o excesso de moléculas de água. Um estudo recentemente publicado sustenta que a desidratação da pele do antebraço ventral induzida, por contacto com sabão alcalino, diminui o RRT ${ }^{(1) \mid}$ donde se infere que a hidratação, deverá aumentá-lo. Os resultados demonstram ainda que, após oclusão, a onda acústica se propaga mais lentamente no grupo II, relativamente ao grupo I apesar de nảo termos conseguido encontrat significado estatístico nestas diferenças. (figura 2)

Admite-se que um RRTmédio mais elevado seja sinónimo de menor elasticidade o que é compativel com as alteraçōes estruturais que se conhecem no processo de envelhecimento e, em especial, na degradação da rede de colagénio-elastina ${ }^{(0)}$. Também no que respeita ao envelhecimento, foi relatado o aumento da anisotropia na face interna do braço e no antebraço ventral de individuos mais velhos ${ }^{06,25 !}$. Contudo, as diferenças de anisotropia encontradas não têm significado estatistico, mesmo após oclusão (Figura 3). 


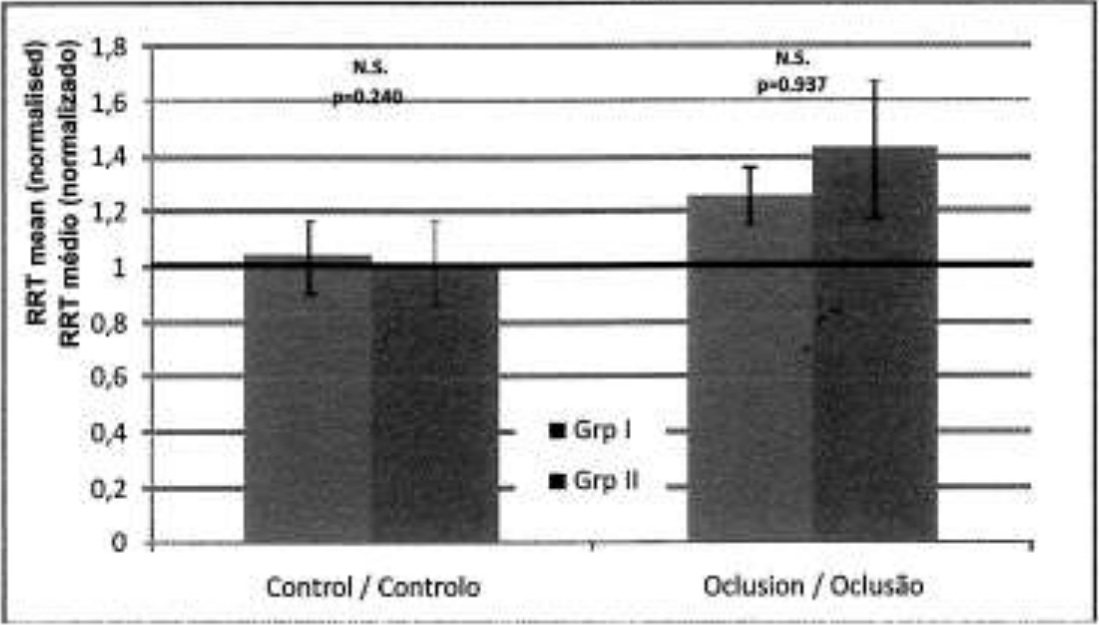

Figure 2 - Graphic illustration of RRTmean values in groups I and II at control and occlusion sites (normalised data so that the line corresponds to " 1 " as the reference value) (N.S. - non significant; ${ }^{*} \mathrm{p}<0.05$ ).

Figura 2 - Resumo gráfico dos valores de RRTmédio nos grupos I e II nas zonas controlo e de oclusão (dados normalizados pelo que a linha a cheio corresponde ao valor "1" de referência). (N.S. - Näo significativo; * p<0.05).

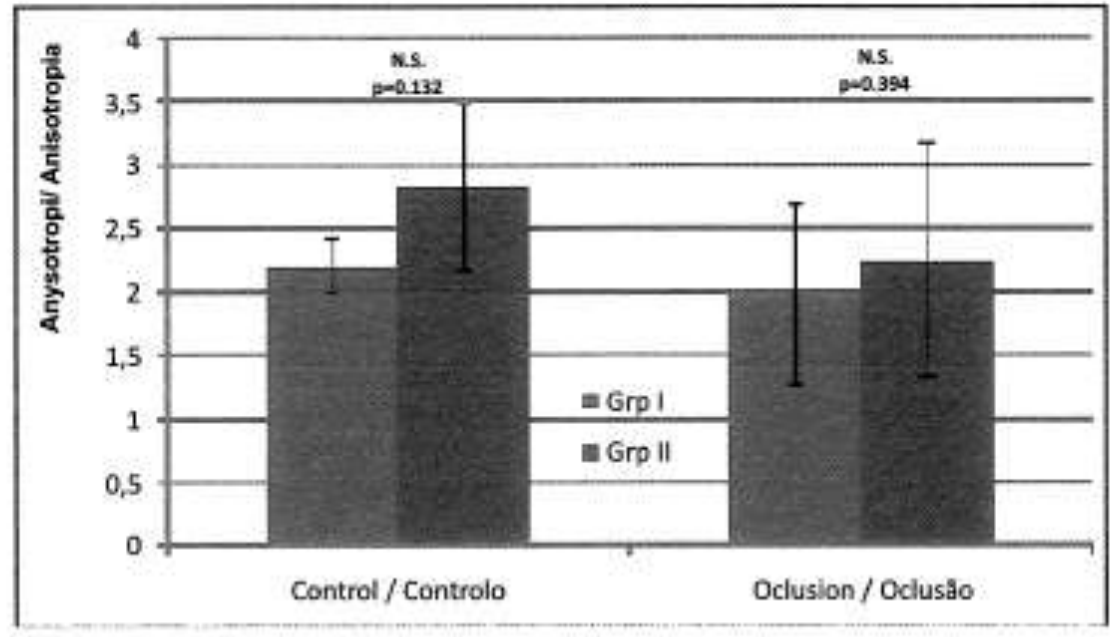

Figure 3 - Graphic illustration of anisotropy values in groups I and II at control and occlusion sites (N.S. - non significant; ${ }^{*} \mathrm{p}<0.05$ ).

Figura 3-Ilustração gráfica dos valores de anisotropia nos grupos I I II, nas zonas de controlo e de oclusăo. (N.S. - Não significativo; ${ }^{*} p<0.05$ ).

In spite of the reduced number of volunteers, it should be expected that the anisotropy in the forearm, that is highly dependent of the influence of the muscles on the skin, would be different from others where the complexity of movements is larger, such as the face ${ }^{(5)}$. In other words, the higher the mobility of the region, the higher should the variation in the mechanical
Apesar do reduzido número de voluntários, seria de esperar que a anisotropia no antebraço que, como em qualquer outra regiaxo, depende da influência dos músculos sobre a pele, seja nessa região, muito diferente de outras onde a complexidade de movimentos é muito maior, como é o caso da face ${ }^{(9)}$. Por outras palavras, quanto maior for a mobilidade da 
directionality of the skin of that region be, which might imply that the forearm might not be the best choice for such type of studies.

The Spearman correlation for the viscoelastic index RRTmean- has shown a total absence of correlation between the two variables in the two studied sites, with low correlation coefficients both in the joint assessment of the two groups and in the isolated assessment of each group (figure 4). regiāo, maior deverá ser a variação da direccionalidade mecânica da pele nessa região, o que não parece fazer do antebraço o melhor sítio anatómico para este tipo de estudos.

A correlação de Spearman para o indice viscoelásticoRRTmédio mostrou ausência total de associação entre as duas variáveis nos dois sites estudados, com coeficientes de correlaçăo muito reduzidos, tanto na avaliação conjunta dos dois grupos como na avaliação isolada de cada grupo (Figura 4).

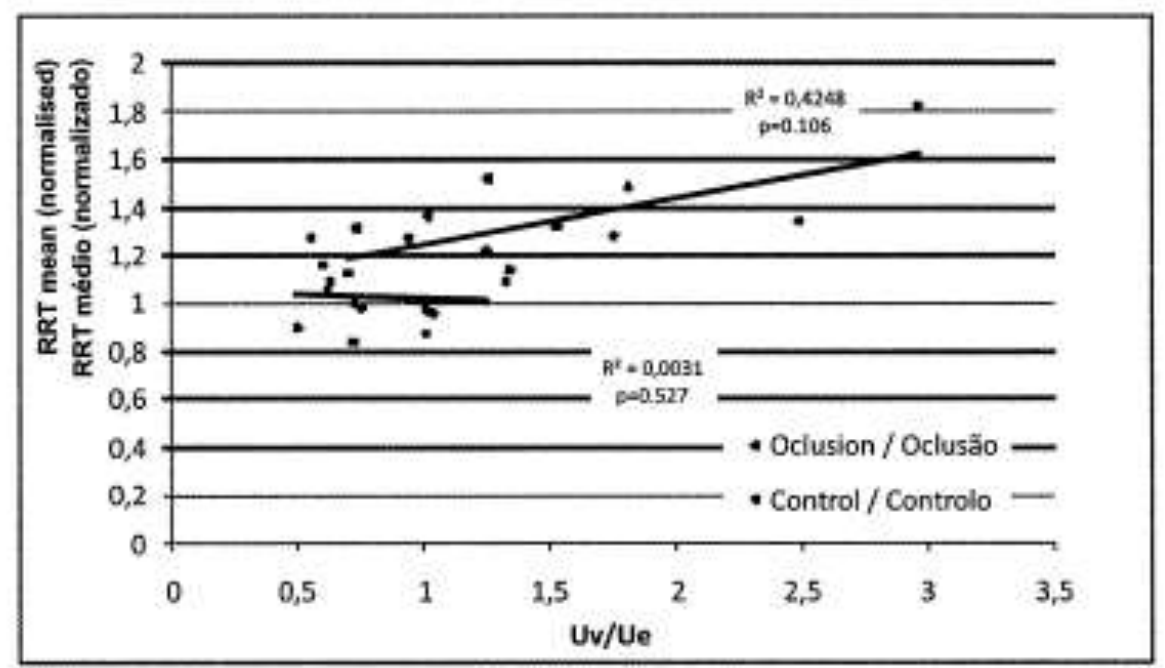

Figure 4 - Graphic presentation of RRTmean (normalized) - Uv/Ue at control and occlusion sites (N.S. - non significant; ${ }^{*} p<0.05$ ).

Figura 4-Representaçāo gráfica das correlaçōes RRTmédio (normalisado)-Uv/Ue nos sitios de controlo e oclusão. (N.S. - Nầo significativo; ${ }^{*} \mathrm{p}<0.05$ ).

\section{Conclusions}

The present experimental conditions didn't allowed to find statistically significant differences regarding the influence of hydration in the studied variables. The number of volunteers seems to be quite insufficient since both groups behaved similarly, no matter the differences between mean ages. Even so, the epidermal overhydration seemed to influence biomechanical behavior and directionality in the upper arm's skin, by increasing RRT and reducing anisotropy. Consistently, these changes were always more pronounced in the older group.

Results suggest the interest in looking further to the many questions raised, specially regarding the influence of the epidermis on the biomechanical behavior of in vivo skin.

\section{Conclusão}

As presentes condiçōes experimentais não permitiram estabelecer diferenças com significado estatístico, acerca da influência da hidratação epidérmica nas variáveis estudadas. $O$ número de voluntários utilizado parece ser manifestamente insuficiente, já que os dois grupos de voluntários, apesar de diferentes do ponto de vista das suas idades médias, tiveram comportamentos semelhantes. Ainda assim, a sobrehidratação da epiderme parece influenciar o comportamento e a direcionalidade biomecânica da pele do antebraço com aumento do RRT e diminuição da anisotropia. $\mathrm{E}$ as variações detectadas foram sempre mais pronunciadas no grupo de individuos mais velhos.

Os resultados sugerem o interesse no aprofundamento das questões aqui levantadas, em especial acerca da influência da epiderme no comportamento biomecânico da pele in vivo. 


\section{Acknowledgements}

The authors would like to thank to all volunteers for their kind cooperation.

\section{Agradecimentos}

Os autores agradecem a disponibilidade e colaboração de todas as voluntárias.

\section{References / Referèncias}

[1]. Pivtrard, G.E, Berandesca, E., Gummer, C.I. Lévéque, J.L. Loden, M. Masson, Ph. Parra, J. I. Rodrigues, L, Rogiers, $V_{i}$, and Threvethen, M EEMOO Guidance to the in vivo assessment of tensile functions of the skin. Part I: relevance of the structures and ageing of the skin fod subcutaneous tisgues, Skin PharmacoL Appl. Skin Physiol, 1999 12:352-362

[2]. Rodrigues L. and the EEMCO Group. EEMCO guidasce to the in vivin assessment of tensile functional properties of the skin. Part 2 instrumentation and test modes. Skin Plamacol Appl Skin Physiol 2001; 14: 52-67.

[3] Langer $\mathrm{K}$, Zur anatomie und physiologie der hast 1. Uever des saltibarkeit der cutis, Sitzungsbe Heidelb Akad Wiss Math Naturwiss KI, 186I; 44: $19-46$

41. Jor J, Nielsen PM, Nash MP, Hunter. PJ, Modelling collagen fiber arientation in porcine skin based upon confocal laser scanning microscopy. Skin Res and Technol.,2011: 17: 149-159

(5) Oshima H, Tada A, Kannmaru A, Akamatsa H, Sakai Y, Itoh M, Kanto $H$, Relevance of the directionality of skin elasticity to aging and sagging of the face, Skin Res and ToctanoL, 2011; 17: 101

[6]. Bush J, Fereuson MW, Mason T, MeGroucher G The dyatmic rotation of Langer's lines on facia expressiun.J Plast Reconstr Aesthet Surg 2007; 60: $393-39 \%$

[7]. Finlay B. Seanning electron microscopy of the buman dermis under uni-axial strain. Biomed Eng $1969 ; 4 ; 322-327$

8]. Meyer W, Neurand K, Radke B. Collagen fibee arrangement in the skin of the pig. JAnut 1982;134. $139-148$
[9] Brown 1A. Scanning electron micreecopy of human dermsl fibrous tissue. J Anat 1972; 113. $159-168$

10]. Pope FM, Martin GR, Lichtenstein JR Penttinen R, Gersen B, Rowe DW, McKusick VA Patients with Filers-Danles syodrome type TV lack type III collagen. Proc Natl Acad Sci USA 1975; 72 $1314-1316$

[11] van Zuijlen P, Ruurda J, van Veen H, van Marke J, van Trier A, Groenevelt F, Kreis R, Middelkoco E Collapes morphology in truman skin ked sese tissee so adaptations in resperse to mecharrical loading at joints, Burns 2003;29:423,431

[12] Young AA, Legrice I, Young MA, Smsill BH. Extended confocsil microscopy of myocardial laminae and collagen network. I Microse 1998; 192 $139-150$

[13]. Courage + Khazska electronic GmbH. Information and Operating Instructioss for the Reviscomeser0 RVM600

[14]. Paye M, Mac-Mary S, Elkhyat A, Tarrit $C$ Mermet Pe Humbert PH. Use of the Reviscometero for measuring cosmerics-induced skin surfuce effects. Skin Res Technol 2007; 13: 343.349.

[15]. Bush J, Ferguson MW, Mason T, MeGroutbet G. The dyramic rotation of Langet's lines on facial expression. I Plast Reconstr Aestbet Surg 2007; 60 ; 393-399

[16],.Ruvolo EC h, Stamatas GN, Kolliss N. Skin viscoelasticity displays site and ase-dependent angular anisatropy. Skin Pharmacol Physiol 2007; 20: $313-321$

[17]. WMA Declaration of Helsinky. Ethica Principles for Modical Research Tavolving Husnan Sobjects, and suceessive amendments umit 2008 (bttpi/wwwiwma net/en/30publications'10policies/ b3/index html.)

[18]. Note for Guidanoe on Good Clinical Practice, ICHE6GCP96, EMEA, 2002: 1-55.

[19]. Barel AO, Counge W, Clarys P. Sactioe method for messurement of skin mechanical properties; the Cutoencter. In: Serup J, Jemec GBE, eds. Handbook of son-invasive methods and the skin. Boca Ratan: CRC Press 335-340

[20]. Rosado C, Rodrigues LM Assessmeat of dry skin using dynamic methods. J Apol Cosmetol 2006 ; 24: 139-15?

[21], Pinto PC, and Rodrigues LM. Influence of the time of occlusion on the quantitative paramet 6. abtained by modelling trass-epidermal water loss curves to deseribe be human cutaneous barrier function in vivo. Mod Biol Eng Compat 2005; 43 : $771-775$.

[22]. Pinto P. Rassdo, C. Parreirio, C., Rodrigues, L. Is there any barrier impairment in sensitive skin?; a quantitative analysis of sensitive skin by matbematical modeling of transepidermal water loss desorptian curves, Skin Res Technol , 2011, (17) $181-185$

[23]. Dobrey H. Use of cutometer to assess epidermal hydration. Skin Res Technol. 2000,6(4):239.44

(24). Ryu HS, Joo YH, Kim SO, Purk KC, Youn SW. Influence of age and regional differences on skin elasticity as mensured by the Cutometere. Skin Res Tectinol 2008: 14:354-35:

[25] Hermanns LT, Jcoilet F, Scheen A, Piérand GE, Ago- and body mass index-related changes in cutaecous sbear wave velocity. Exp Gercotol 2001; 36: $363-372$ 